\title{
PENERAPAN KEBIJAKAN GREEN ECONOMY PADA 7 SEKTOR INDUSTRI KECIL \& MENENGAH DI JAWA TIMUR
}

\author{
Alvin Sugeng Prasetyo \\ alvin.prasetyo@ trunojoyo.ac.id \\ Fakultas Ekonomi dan Bisnis Universitas Trunojoyo Madura \\ Jalan Raya Telang, Kamal - Bangkalan, 69162
}

\begin{abstract}
ABSTRAK
Jawa Timur merupakan salah satu provinsi yang mendukung pelaksaan ekonomi hijau. Oleh sebab itu, jika Jawa Timur bisa mewujudkan pembangunan ekonomi hijau, maka pembangunan berkelanjutan semakin menguntungkan tidak hanya untuk masa sekarang tetapi juga untuk masa depan. Tujuan penelitian ini yaitu mengidentifikasi dan menganalisis green economy pada sektor Industri. Sampel sektor industri sebanyak 12 industri, karena terkendala pembatasan wilayah untuk mengurangi kasus Covid-19 sehingga banyak industri yang tutup. Ketegori industri hijau atau tidak menggunakan indikator ekonomi hijau yang dikeluarkan oleh Kementerian Lingkungan Hidup dan Kehutanan, kemudian menggunakan analisis DEA untuk mengetahui efisiensi industri, selanjutnya menggunakan SWOT untuk merumusakan strategi kebijakan. Hasil penelitian menunjukkan bahwa banyak industri di Jawa Timur memiliki nilai efisiensi dibawah angka satu, kemudian sampel industri yang digunakan penelitian belum masuk ketegori industri hijau.
\end{abstract}

Kata Kunci: Ekonomi Hijau, Efisiensi, SWOT, DEA

\begin{abstract}
East Java Province is one of the provinces that supports the implementation of a green economy. Therefore, if the province of East Java can implement a green economy, then sustainable development will be more profitable not only for the present but also for the future. The purpose of this study is to identify and analyze the green economy in the industrial sector. The sample of the industrial sector is 12 industries, due to the constraints of regional restriction policies to reduce Covid-19 cases, so many industries are closed. The category of green industry or not uses green economy indicators issued by the Ministry of Environment and Forestry, then uses DEA analysis to determine industrial efficiency, then uses SWOT to formulate policy strategies. The results showed that many industries in East Java had efficiency values below the number one, then the industrial samples used in the study had not yet entered the green industry category.
\end{abstract}

Keywords: Green Economy, Efficiency, SWOT, DEA

\section{PENDAHULUAN}

Salah satu provinsi yang mendukung pelaksaan ekonomi hijau, yaitu provinsi Jawa Timur. Jawa Timur merupakan salah satu provinsi yang dianugerahi sumber daya alam yang melimpah (Putri, 2020). Potensi kekayaan alam mampu membuat Jawa Timur menjadi salah satu provinsi yang mendorong perekonomian Nasional (Astutiningsih \& Sari, 2017). Oleh sebab itu, jika Jawa Timur bisa mewujudkan pembangunan ekonomi hijau, maka pembangunan berkelanjutan akan semakin menguntungkan tidak hanya untuk masa sekarang tetapi juga untuk masa depan.

Kontribusi ekonomi Jawa Timur terhadap perekonomian nasional tertinggi kedua setelah DKI Jakarta, artinya Jawa Timur menjadi salah satu penyangga ekonomi nasional. Awal 2015 sampai 2016 kontribusi ekonomi Jawa Timur meningkat dari 14,52 persen menjadi 14,7 persen. Hal ini memberikan arti bahwa pengaruh Jawa Timur pada perekonomian nasional mengalami peningkatan. Namun, pasca periode 2016 sampai periode 2020 kontribusi ekonomi Jawa Timur dalam ekonomi nasional memiliki tren menurun.

Namun, pertumbuhan ekonomi Jawa Timur di atas pertumbuhan ekonomi Nasional sampai dengan 2019, sehingga kinerja ekonomi cukup baik pada periode tersebut. Kinerja ekonomi Jawa Timur 2020 mengalami kontraksi. Pertumbuhan ekonomi Jawa Timur tahun 2020 sebesar -2,39 persen. Perlambatan terjadi pada hampir seluruh komponen permintaan akibat pandemi COVID-19 dan berdampak pada penurunan konsumsi swasta, konsumsi pemerintah, investasi, dan net ekspor antar daerah. Pandemi COVID-19 turut menekan sektor investasi bangunan dan konstruksi akibat realokasi dan refocusing anggaran pemerintah serta penjadwalan ulang proyek pemerintah dan swasta akibat kebijakan pembatasan aktivitas ekonomi (Assidikiyah et al., 2021).

Kontribusi ekonomi Jawa Timur terhadap perekonomian Nasional dan pertumbuhan ekonomi Jawa Timur kembali mengalami peningkatan pada periode 2021 Triwulan I. Hal ini memberikan arti bahwa ekonomi Jawa Timur mulai bangkit, meskipun angka pertumbuhan ekonomi masih negatif. Perbaikan 
tersebut di dorong oleh beberapa hal seperti peningkatan produksi padi karena masa panen, peningkatan sektor industri yang disebabkan peningkatan permintaan domestik, dan relaksasi pajak PPnBM. Provinsi Jawa Timur telah mendesain anggaran belanja daerah 2021 melalui program 'Jatim Bangkit'. Anggaran Jawa Timur sebesar 50\% diarahkan kepada sektor esensial seperti pendidikan dan kesehatan. Sektor utama yang mendorong PDRB Jawa Timur yaitu industri pengolahan, sektor perdagangan besar dan eceran, serta pertanian, kehutanan, dan perikanan menjadi. Hal ini memberikan arti bahwa tiga sektor tersebut memiliki peran yang cukup besar terhadap kinerja ekonomi Jawa Timur. Sektor industri pengolahan memiliki kontribusi yang cukup tinggi dibandingkan dengan sektor lain, sehingga menjadi sektor yang strategis.

Kontribusi industri pengolahan tahun 2020 mengalami penurunan. Hal ini karena penurunan permintaan global dan domestik serta penurunan pendapatan masyarakat karena pandemi. Permintaan global dan domestik menurun menyebabkan produksi industri tidak optimal. Kontribusi industri Jawa Timur mengalami penurunan di tahun 2020 tidak berlangsung lama. Kontribusi tersebut mengalami peningkatan di tahun 2021, dari 30,69 persen menjadi 30,94 persen. Hal ini menjadi tanda bahwa sektor industri mulai bergerak, sehingga produktivitas industri kembali meningkat.

Pertumbuhan industri pengolahan di Jawa Timur secara y-on-y dan c-to-c memiliki pola yang sama. Pertumbuhan industri pengolahan di Jawa Timur mulai tahun 2015-2019 baik secara y-on-y maupun secara c-to-c memiliki tren yang meningkat. Hal ini memberikan arti bahwa sektor industri di Jawa Timur mengalami perbaikan, sehingga aktivitas industri di Jawa Timur kembali mengalami peningkatan. Perbaikan sektor industri pengolahan ini ini sejalan dengan implementasi kebiasaan normal baru yang mendorong kinerja industri pengolahan (Sutikno et al., 2021). Faktor lain yang mendorong perbaikan industri pengolahan Jawa Timur, yaitu relaksasi PPH pasal 21 untuk pekerja di industri pengolahan yakni sebanyak 189 bidang industri dengan pendapatan hingga Rp200 juta per tahun.

Industri pengolahan sebagai mesin pertumbuhan ekonomi Jawa Timur memunculkan masalah trade-off dengan upaya pelestarian lingkungan. Sumber pertumbuhan industri pengolahan Jawa Timur hingga saat ini masih bertumpu pada pemanfaatan sumber daya alam, sehingga kegiatan industri dan pemanfaatan sumber daya alam yang terjadi secara terus menerus akan menimbulkan eksternalitas negatif bagi lingkungan hidup berupa pencemaran dan kerusakan lingkungan (Sjafii, 2009). Eksternalitas negatif terjadi ketika proses pabrik di Jawa Timur menimbulkan dampak negatif seperti membuang limbah disungai yang berakibat pada pencemaran air atau menimbulkan polusi udara sehingga terjadi pencemaran lingkungan (Putri, 2020). Penduduk disekitar pabrik akan menanggung biaya eksternal dari kegiatan ekonomi tersebut berupa masalah kesehatan, kesulitan mengakses air bersih, serta berkurangnya udara bersih. Oleh sebab itu, peningkatan pertumbuhan ekonomi Jawa Timur yang tinggi didorong oleh sektor industri, ternyata belum disertai dengan kinerja pengelolaan lingkungan yang memuaskan.

Perkembangan indeks kualitas air Jawa Timur dari tahun 2015-2019 termasuk dalam kategori sangat kurang. Hal ini disebabkan karena adanya pencemaran kualitas air yang bersumber dari kegiatan permukiman dan industri terutama Usaha Mikro Kecil dan Menengah (UMKM) yang belum dilengkapi dengan sarana pengolahan air limbah yang memadai serta masih ditemuinya sampah rumah tangga yang dibuang langsung ke sungai. Sampah merupakan salah satu ancaman terhadap lingkungan termasuk pada sungai yang harus diantispasi karena seiring dengan meningkatnya laju pertumbuhan penduduk di Jawa Timur serta adanya perubahan pola konsumsi masyarakat akan mengakibatkan bertambahnya volume timbunan sampah.

Indeks kualitas air tahun 2015-2018 masih dibawah Nasional, sedangkan pada tahun 2019 kualitas air Jawa Timur diatas Nasional. Hal ini berarti kualitas air lebih baik dari sebelumnya, namun masih mengalami ancaman dan gangguan limbah. Indeks kualitas air mengalami peningkatan tidak terlepas dari program pembinaan, pengawasan, susur sungai, patroli air, sidak, penilaian program peringkat kinerja lingkungan industri (PROPER) dan penegakan hukum oleh Pemerintah Daerah Provinsi Jawa Timur.

Beberapa upaya Pemerintah Provinsi Jawa Timur untuk mengendalikan pencemaran udara, yaitu melalui pembinaan pengelolaan lingkungan bagi pelaku industri dan kegiatan usaha lainnya; pengawasan dan penegakan hukum lingkungan; serta pemantauan kualitas udara secara rutin pada kawasan pemukiman, perkantoran, industri dan lalu lintas yang padat. Pemerintah Provinsi Jawa Timur juga terus mendorong Pemerintah Kabupaten/Kota untuk meningkatkan Ruang Terbuka Hijau (RTH) 
(Prianto \& Sulhan, 2020). IKLH (Indeks Kualitas Lingkungan Hidup) adalah instrumen yang digunakan untuk mengukur capaian kinerja program perlindungan dan pengelolaan lingkungan hidup (Anom et al., 2021). IKLH Jawa Timur dan Nasional masuk dalam ketegori cukup, karena masuk dalam rentang poin 66-74.

Peningkatan jumlah industri di Jawa Timur dapat menjadi ancaman meningkatnya potensi pencemaran terhadap lingkungan, jika limbah yang dihasilkan baik itu limbah cair, limbah padat maupun gas tidak dikelola dengan baik. Oleh sebab itu, konsep industri hijau perlu dianalisis lebih lanjut. Landasan hukum industri hijau di Jawa Timur didasarkan pada perda No. 3 tahun 2019 tentang Rencana Pembangunan Industri Provinsi (RPIP). RPIP Jawa Timur disusun bertujuan untuk mempercepat tumbuhnya Industri hijau (green industries) sebagai bagian percepatan terwujudnya smart environment di Jawa Timur. Dengan penerapan industri hijau di Jawa Timur, maka terjadi efisiensi bahan baku dan industri serta meningkatkan daya saing (Sjafii, 2009).

Undang-Undang RI No. 3 Tahun 2014 Tentang Perindustrian, disebutkan bahwa "Industri Hijau adalah Industri yang dalam proses produksinya mengutamakan upaya efisiensi dan efektivitas penggunaan sumber daya secara berkelanjutan sehingga mampu menyelaraskan pembangunan industri dengan kelestarian fungsi lingkungan hidup serta dapat memberikan manfaat bagi masyarakat". Industri hijau adalah aktivitas yang: (1) increase the effectiveness of energy and resources through entire economy and (2) minimize the emission of green house gas and pollution, and that accomplish low carbon green growth through products and services that can improve environment. Penerapan industri hijau dilakukan melalui konsep produksi bersih (cleaner production) melalui aplikasi 4R, yaitu reduce (pengurangan limbah pada sumbernya), reuse (penggunaan kembali limbah), dan recycle (daur ulang limbah), serta recovery (pemisahan suatu bahan atau energi dari suatu limbah).

Suzantho \& Hadi (2018) melakukan penelitian tentang industri hijau pada industri kecil dan menengah di Surabaya. Hasil penelitian menunjukkan bahwa pemahaman pelaku industri kecil dan menengah di Surabaya tentang permasalahan lingkungan masih rendah, sehingga menuju industri hijau masih butuh proses yang tidak sebentar. Oleh sebab itu perlu dilakukan secara kesinambungan dengan dibarengi kegiatan pembinaan. Edukasi yang perlu diberikan khususnya terkait dengan perkembangan teknologi proses produksi dan manajemen lingkungan, sehingga menghasilkan green product. Septiriana \& Kusumawardani (2016) melakukan penelitian tentang efisiensi energi pada industri pengolahan di Jawa Timur. Hasil penelitian menunjukkan bahwa faktor yang terbukti berpengaruh siginifikan terhadap efisiensi energi industri pengolahan terdiri dari: keberadaan investasi asing, jenis perusahaan (processing atau assembly), composition effect, scale effect dan technical effect.

Berdasarkan pada uraian latar belakang, maka inti persoalan dalam kajian ini yaitu peningkatan pertumbuhan ekonomi Jawa Timur yang tinggi didorong oleh sektor industri, ternyata belum disertai dengan kinerja pengelolaan lingkungan yang memuaskan.Kontribusi sektor industri pengolahan yang semakin besar merupakan pertanda bahwa terjadi peningkatan jumlah industri di Jawa Timur, sehingga menjadi ancaman meningkatnya potensi pencemaran terhadap lingkungan, jika limbah yang dihasilkan baik itu limbah cair, limbah padat maupun gas tidak dikelola dengan baik. Oleh sebab itu, konsep industri hijau di Jawa Timur yang tertuang dalam Rencana Pembangunan Industri Provinsi (RPIP) perlu dianalisis lebih lanjut.

\section{METODE PENELITIAN}

Analisis tentang industri hijau dalam penelitian ini menggunakan sampel industri di Jawa Timur. Industri yang digunakan sampel terlebih dahulu dihitung efisiensi energi-nya, selanjutnya, melakukan klasterisasi industri hijau berdasarkan penilaian yang diberikan oleh Kementerian Perindustrian. Setiap industri memiliki penelitian yang berbeda-beda, maksudnya penelitian pada industri kecil, menengah, dan besar tidak sama. Tahap berikutnya menggunakan metode SWOT untuk menganalisis lebih mendalam strategi industri hijau di Jawa Timur.

Jenis data yang digunakan dalam studi ini ada yang bersifat primer dan ada yang bersifat sekunder. Bersifat primer karena di peroleh secara langsung dari sumber pertama (tidak melalui perantara), baik individu maupun kelompok. Kajian ini memperoleh data primer melalui survey dengan cara interview atau pembagian kuesioner pada industri yang jadikan sampel.

Nantinya pengambilan data primer berdasarkan kriteria penilaian, seperti proses produksi terdiri dari bahan baku, bahan penolong air, teknologi proses, hasil produksi ( bobot 70\%), manajemen perusahaan yang terdiri dari program efisiensi produksi, system manajemen, penghargaan yang pernah diterima 
(bobot 20\%), sedangkan pengelolaan lingkungan yang terdiri dari penyediaan bahan baku mutu lingkungan, sarana pengelola limbah dan emisi, kinerja pengelolaan lingkungan (bobot 10\%).

Perusahaan industri dapat dikategorikan memiliki komitmen terhadap upaya penerapan industri hijau, jika dapat memenuhi paling sedikit 50\% dari setiap aspek penilaian. Perusahaan industri yang dapat memenuhi setiap aspek penilaian dengan persentase di atas 90\%, dapat dikategorikan sebagai perusahaan yang telah menerapkan prinsip industri hijau secara berkelanjutan. Selanjutnya jenis data sekunder yang diperoleh berdasarkan lembaga yang terpecaya seperti BPS, Kementerian Industri, Kementerian Lingkungan Hidup dan Kehutanan, dan lain-lain.

DEA (Data Envelopment Analysis) berfungsi untuk mengukur efesiensi suatu organisasi yang melibatkan banyak input dan banyak output (multi input multi output) (Sutawijaya \& Lestari, 2009). Metode Data Envelopment Analysis (DEA) merupakan suatu metode analisis non parametrik yang khusus digunakan untuk mengukur efisiensi unit kegiatan ekonomi yang dinamakan Decision Making Unit (DMU) (Firdaus \& Hosen, 2014). Metode DEA mampu menganalisis banyak input dan banyak output dengan menggunakan program linier guna menghasilkan nilai efisiensi tunggal untuk setiap Decision Making Unit (DMU). Inti dari metode DEA pada dasarnya adalah menetukan bobot atau timbangan setiap input dan output DMU yang tidak bernilai negatif dan bersifat universal.

Prinsip pendekatan non parametrik menggunakan metode DEA pertama kali diperkenalkan oleh Farrell (1957). Akan tetapi ide Farrell tersebut kurang mendapat perhatian luas. Dalam perkembangannya, metode ini kemudian dikembangkan oleh Charnes, Cooper, dan Rhodes (1978) yang memunculkan istilah Data Envelopment Analysis (DEA). Model DEA yang dikembangkan oleh Charnes, Cooper, dan Rhodes (1978) ini kenal dengan sebutan model CCR. Dalam analisisnya, model CCR menggunakan asumsi constant return to scale (CRS) dimana rasio penambahan input dan output adalah sama. Pada tahun 1984, Banker, Charnes, dan Cooper mengembangkan sebuah model yang dinamakan model BCC. Berbeda dengan model CCR, model BCC ini menggunakan asumsi adanya variable return to scale 30 (VRS), yaitu rasio penambahan input dan output tidak sama. Rasio penambahan input dan output dapat berupa increasing return toscale (IRS) atau decreasing return to scale (DRS) (Tuffahati et al., 2019).

Terdapat dua orientasi yang digunakan dalam metodologi pengukuran efisiensi, yaitu orientasi input yang melihat efisiensi sebagai pengurangan penggunaan input meski memproduksi output dalam jumlah yang tetap. Cocok untuk industri dimana manager memiliki kontrol yang besar terhadap biaya operasional. Orientasi Output Prespektif yang melihat efisiensi sebagai peningkatan output secara proporsional dengan menggunakan input yang sama. Cocok untuk industri dimana unit pembuat keputusan diberikan kuantitas resource dalam jumlah yang fix dan diminta untuk memproduksi output sebanyak mungkin dari resource tersebut.

Penelitian ini juga menggunakan analisis SWOT berdasarkan konsep David (1993). Melalui analisis SWOT, akan membantu dalam penyimpulan akhir penelitian. Analisis SWOT menggunakan matriks internal factor evaluation (IFE) dan matriks eksternal factor evaluation (EFE), dimana IFE yang meliputi kekuatan dan kelemahan dan EFE meliputi peluang dan tantangan (Setyaningsih, 2018). Gambar 5 menampilkan delapan kotak, yaitu dua kotak sebelah kiri menampilkan faktor eksternal (peluang dan ancaman), dua kotak paling atas menampilkan faktor internal (kekuatan dan kelemahan) dan empat kotak lainnya merupakan isu-isu strategis yang timbul sebagai hasil pertemuan antara faktor eksternal dan internal (Noor, 2014). 


\begin{tabular}{|c|c|c|}
\hline IFAS & $\begin{array}{c}\text { Kekuatan/Strengths(S) } \\
\text { Faktor-faktor kekuatan } \\
\text { internal }\end{array}$ & $\begin{array}{c}\text { Kelemahan/Weaknesses(W) } \\
\text { Faktor-faktor kelemahan } \\
\text { internal }\end{array}$ \\
$\begin{array}{c}\text { Faktor - } \\
\text { faktorpeluang } \\
\text { eksternal }\end{array}$ & $\begin{array}{c}\text { Ciptakan strategi yang } \\
\text { menggunakan kekuatan } \\
\text { untuk memanfaatkan } \\
\text { peluang }\end{array}$ & $\begin{array}{c}\text { Strategi WO } \\
\text { meminimalkan kelemahan } \\
\text { untuk memanfaatkan } \\
\text { peluang }\end{array}$ \\
\hline $\begin{array}{c}\text { Faktor-faktor } \\
\text { ancaman eksternal }\end{array}$ & $\begin{array}{c}\text { Ciptakan strategi yang } \\
\text { menggunakan kekuatan } \\
\text { untuk mengatasi ancaman }\end{array}$ & $\begin{array}{c}\text { Ciptakan strategi yang } \\
\text { meminimalkan kelemahan } \\
\text { dan menghindari ancaman }\end{array}$ \\
\hline
\end{tabular}

\section{Gambar 1 \\ Analisis SWOT}

Terdapat lima langkah dalam mengembangkan EFE, yaitu:

1. Tuliskan faktor-faktor eksternal yang menjadi peluang dan ancaman perusahaan. Gunakan 10 - 20 faktor eksternal terpenting yang mempengaruhi perusahaan dan industrinya. Tuliskan peluang perusahaan terlebih dahulu kemudian ancaman perusahaan. Usahakan sespesifik mungkin gunakan prosentase, rasio dan angka perbandingan.

2. Berikan bobot pada masing-masing faktor dengan kisaran 0,0 (tidak penting) hingga 1,0 (sangat penting). Bobot yang diberikan pada suatu faktor menunjukkan kepentingan yang relatif untuk mengetahui kesuksesan dalam industri yang ditekuni perusahaan. Peluang sering mendapat bobot lebih tinggi dari ancaman, tetapi ancaman juga akan mendapat bobot lebih tinggi apabila terdapat faktor yang sangat mengancam. Bobot yang wajar ditentukan dengan membandingkan pesaing yang sukses dengan yang gagal. Jumlah dari semua bobo tersebut harusa sama dengan 1.

3. Berikan peringkat 1 hingga 4 pada setiap faktor untuk menunjukkan bahwa faktor tersebut mempunyai tidak berdampak (peringkat $=1$ ), mempunyai dampak (peringkat $=2$ ), berdampak kecil (peringkat $=3$ ), berdampak besar (peringkat $=4$ ). Peringkat diberikan berdasarkan keadaan perusahaan, sedangkan bobot dalam langkah ke-2 didasarkan keadaan industri.

4. Kalikan setiap bobot dari faktor tersebut dengan peringkat untuk menentukan nilai bobot untuk setiap variabel.

5. Jumlahkan nilai yang dibobot untuk setiap variabel untuk menentukan total nilai yang dibobot untuk organisasi/perusahaan.

Total nilai yang dibobot tertinggi adalah 4,0 dan terendah adalah 1,0 dengan rata-rata 2,5. Jika perusahaan berbobot dibawah 2,5 perusahaan dinilai lemah dalam faktor eksternal, sedangkan jika perusahaan berbobot diatas 2,5 maka perusahaan dalam keadaan eksternal yang kuat.

IFE adalah suatu alat untuk meringkas dan mengevaluasi kekuatan dan kelemahan utama dalam berbagai bidang fungsional dari suatu usaha, matriks ini juga memberikan dasar untuk mengenali dan mengevaluasi hubungan di antara bidangbidang ini (Chrismastianto, 2017). Matriks IFE dapat dijelaskan melalui lima langkah penilaian sebagai berikut:

1. Tuliskan faktor-faktor yang menjadi kekuatan dan kelemahan perusahaan. Gunakan $10-20$ faktor internal terpenting. Tuliskan kekuatan perusahaan terlebih dahulu kemudian kelemahan perusahaan. Usahakan sespesifik mungkin gunakan prosentase, rasio dan angka perbandingan.

2. Berikan bobot pada masing-masing faktor dengan kisaran 0,0 (tidak penting) hingga 1,0 (sangat penting). Bobot yang diberikan pada suatu faktor menunjukkan kepentingan yang relatif untuk mengetahui kesuksesan dalam industri yang ditekuni perusahaan. Faktor-faktor yang dianggap berpengaruh besar pada prestasi organisasi/perusahaan diberi nilai bobot tertinggi. Jumlah dari semua bobo tersebut harusa sama dengan 1 . 
3. Berikan peringkat 1 hingga 4 pada setiap faktor untuk menunjukkan bahwa faktor tersebut mempunyai kelemahan utama (peringkat $=1$ ), kelemahan kecil (peringkat $=2$ ), kukuatan kecil (peringkat $=3$ ), kekuatan utama (peringkat $=4$ ). Peringkat diberikan berdasarkan keadaan perusahaan, sedangkan bobot dalam langkah ke-2 didasarkan keadaan industri.

4. Kalikan setiap bobot dari faktor tersebut dengan peringkat untuk menentukan nilai bobot untuk setiap variabel.

5. Jumlahkan nilai yang dibobot untuk setiap variabel untuk menentukan total nilai yang dibobot untuk organisasi/perusahaan.

Jika total nilai yang dibobot jauh dibawah 2,5 maka perusahaan tersebut lemah dalam internal, sedangkan jika total bobot diatas 2,5 maka perusahaan tersebut berada pada posisi internal yang kuat.

Tabel 1

Sampel Penelitian

\begin{tabular}{llll}
\hline Industri & Jenis Industri & Nama Industri & Lokasi \\
\hline Industri Makanan & Kecil & Dapur Bu Dewi & Surabaya \\
Industri Makanan & Sedang & Depot Bu Ima & Surabaya \\
Industri Pengolahan Makanan & Sedang & CV Pangan Berkah Sentosa & Jombang \\
Industri Konveksi & Sedang & CV Pijar Konveksi & Jombang \\
Industri Pupuk & Sedang & Tiara Kurnia & Malang \\
Industri Furniture & Kecil & Hardi Furniture & Bangkalan \\
Industri Sandal & Sedang & Oppoa & Malang \\
\hline
\end{tabular}

Tabel 1 menunjukkan ada 7 industri yang digunakan dalam studi ini sebagai sampel. Lokasi industri di Surabaya, Jombang, Malang, dan Bangkalan. Sampel-sampel tersebut akan dianalisis termasuk dalam kategori industri hijau atau tidak.

\section{HASIL DAN PEMBAHASAN}

Efisiensi merupakan nilai tambah yang dihasilkan suatu industri dengan input yang digunakan berupa tenaga kerja, bahan baku, modal dan lainnya. Efisiensi dalam produksi tidak bisa lepas dari alokasi input dalam produksi. Suatu perusahaan dikatakan beroperasi secara efisien jika ada realokasi terhadap faktor produksi guna meningkatkan produksi salah satu barang tanpa mengurangi produksi barang lain. Pengukuran efisien atau tidak efisien industri diukur dengan ukuran yang relatif. Apabila terjadi kecenderungan peningkatan efisiensinya dari tahun ke tahun maka dapat digolongkan industri ini efisien dan apabila terjadi penurunan efisiensi maka dapat dikatakan bahwa industri belum efisien atu tidak efisien.

Masih banyak industri di Jawa Timur yang belum efisien. Hal ini karena score efisiensi yang kurang dari 1. Hasil ini memberikan arti bahwa input yang digunakan dalam proses produksi masih belum optimal, sehingga diharapkan masing-masing perusahaan lebih mengoptimalkan input dengan mengkombinasi input yang tepat. WFH (work from home) memang dapat mengurangi penggunaan energi di industri, tetapi menjadi kurang efektif ketika banyak pekerjaan dalam industri yang tidak dapat dikerjakan secara remote. Para pelaku industri dan pembuat desain fasilitas industri harus mengetahui cara efisiensi energi yang efektif. Oleh sebab itu, dimasa pendemi ini dapat dijadikan momentum untuk mengimplementasikan ekonomi hijau.

Upaya menganalisa lingkungan eksternal dan internal pelaksanaan industri hijau penting untuk dilakukan. Lingkungan eksternal terdiri dari semua keadaan, baik itu peluang ataupun ancaman yang akan mempengaruhi pilihan strategik, serta penentuan situasi pelaksanaannya. Lingkungan internal akan menggambarkan kuantitas dan kualitas sumber daya manusia, keuangan dan fisik pengelola program. Lingkungan internal juga akan menilai kekuatan dan kelemahan manajemen dan struktur organisasi pelaksana program penerapan industri hijau. 
Tabel 2

Matrik Internal Factor Evaluation (IFE)

\begin{tabular}{|c|c|c|c|c|}
\hline No & Aspek Internal & Bobot & Rating & Nilai \\
\hline \multirow[t]{7}{*}{1} & Kekuatan (Strength) & & & \\
\hline & $\begin{array}{l}\text { - Ada kebijakan dan regulasi Pemprov (Perda } \\
\text { RPIP) dan Pemkab (Perda RPIK) }\end{array}$ & 0.14 & 4 & 0.56 \\
\hline & $\begin{array}{l}\text { - Ada program dan kegiatan OPD lintas sektoral } \\
\text { terkait industri hijau }\end{array}$ & 0.13 & 4 & 0.52 \\
\hline & - Ada laporan kegiatan terkait industri hijau & 0.15 & 4 & 0.60 \\
\hline & - Ada lembaga sertifikasi industri hijau & 0.14 & 4 & 0.56 \\
\hline & $\begin{array}{l}\text { - Ada program penilaian kinerja industri hijau } \\
\text { (Proper) }\end{array}$ & 0.13 & 4 & 0.52 \\
\hline & & & & 2,76 \\
\hline \multirow[t]{7}{*}{2} & Kelemahan (Weakness) & & & \\
\hline & $\begin{array}{l}\text { - } \begin{array}{l}\text { Sinergitas kegiatan antar OPD dan industri } \\
\text { belum optimal }\end{array}\end{array}$ & 0.08 & 2 & 0.16 \\
\hline & - Daya saing industri rendah & 0.05 & 2 & 0.10 \\
\hline & $\begin{array}{l}\text { - Pengetahuan dan kesadaran pentingnya industri } \\
\text { hijau masih rendah }\end{array}$ & 0.07 & 2 & 0.14 \\
\hline & - Tergantung pemerintah pusat & 0.06 & 2 & 0.12 \\
\hline & - Dana insentif masih rendah & 0.05 & 2 & 0,10 \\
\hline & & 1.00 & & 0.62 \\
\hline
\end{tabular}

Tabel 2 diketahui bahwa kekuatan utama yang dimiliki Provinsi Jawa Timur adalah: ada kebijakan dan regulasi Pemerintah daerah (Peraturan Daerah terkait Rencana Pembangunan Industri Propinsi-RPIP) dan Pemerintah kabupaten (Peraturan Daerah tentang Rencana Pembangunan Industri KabupatenRPIK), ada program dan kegiatan dari organisasi perangkat daerah-OPD lintas sektoral terkait industri hijau, ada lembaga sertifikasi industri hijau, ada program kinerja industri hijau dengan skor 2,76. Sedangkan, kelemahan yang dimiliki adalah: Sinergitas kegiatan antar OPD dan industri belum optimal, daya saing industri rendah, pengetahuan dan kesadaran pentingnya industri hijau masih rendah, tergantung pemerintah pusat, dan dana insentif masih rendah dengan skor 0,62. Hasil penggabungan kedua faktor internal (Kekuatan-kelemahan) menghasilkan total skor 3,38.

Tabel 3 diketahui bahwa peluang utama yang dimiliki Provinsi Jawa Timur adalah: komitmen Kepala Daerah besar terkait industri hijau, ada regulasi industri hijau, ada alokasi anggaran program industri hijau, ada dukungan forum corporat social responsible-CSR, ada juknis industri hijau bagi daerah dengan skor 2,49. Sedangkan tantangan yang ada adalah: pergantian pejabat / penanggungjawab program, kesadaran masyarakat rendah terkait industri hijau, kendala geografis dan akses informasi, kebiasaan membuang sampah dan limbah sembarangan, persoalan kesehatan lingkungan dengan skor 0,68 . Hasil penggabungan kedua faktor eksternal (peluang-tantangan) menghasilkan total skor 3,17. 
Tabel 3

Matrik External Factor Evaluation (EFE)

\begin{tabular}{|c|c|c|c|c|}
\hline No & Aspek Eksternal & Bobot & Rating & Nilai \\
\hline \multirow[t]{7}{*}{1} & Peluang (Opportunities) & & & \\
\hline & - Komitmen Kepala Daerah besar terkait industri hijau & 0.14 & 4 & 0.56 \\
\hline & - Ada regulasi industri hijau & 0.13 & 4 & 0.52 \\
\hline & - Ada alokasi anggaran program industri hijau & 0.11 & 3 & 0.33 \\
\hline & - Ada dukungan forum CSR & 0.13 & 4 & 0.52 \\
\hline & - Ada juknis industri hijau bagi daerah & 0.14 & 4 & 0.56 \\
\hline & & & & 2,49 \\
\hline \multirow[t]{8}{*}{2} & Tantangan (Threaths) & & & \\
\hline & - Pergantian pejabat / penanggungjawab program & 0.08 & 2 & 0.16 \\
\hline & - Kesadaran masyarakat rendah terkait industri hijau & 0.07 & 2 & 0.14 \\
\hline & - Kendala geografis dan akses informasi & 0.06 & 2 & 0.12 \\
\hline & $\begin{array}{l}\text { - Kebiasaan membuang sampah dan limbah } \\
\text { sembarangan }\end{array}$ & 0.07 & 2 & 0.14 \\
\hline & - Persoalan kesehatan lingkungan & 0.06 & 2 & 0.12 \\
\hline & & 1.00 & & 0.68 \\
\hline & & & & 3,17 \\
\hline
\end{tabular}

Berdasarkan hasil pengolahan data pada matriks evaluasi internal dan matriks evaluasi eksternal didapatkan besaran nilai dari masing-masing matriks tersebut, yang kemudian menjadi masukan untuk analisa kuadran. Nilai Matriks Evaluasi Internal $=$ Total Kekuatan - Total Kelemahan $=2,76-0,62=$ 2,14. Nilai Matriks Evaluasi Eksternal $=$ Total Peluang - Total Ancaman $=2,49-0,68=1,81$. Posisi pelaksanaan industri hijau di Jawa Timur dalam wilayah Kuadran I (bertumbuh). Posisi ini menggambarkan bahwa strategi bertumbuh untuk pelaksanaan industri hijau sangat dimungkinkan karena kekuatan lebih besar dari pada kelemahan dan peluang lebih besar dari ancaman.

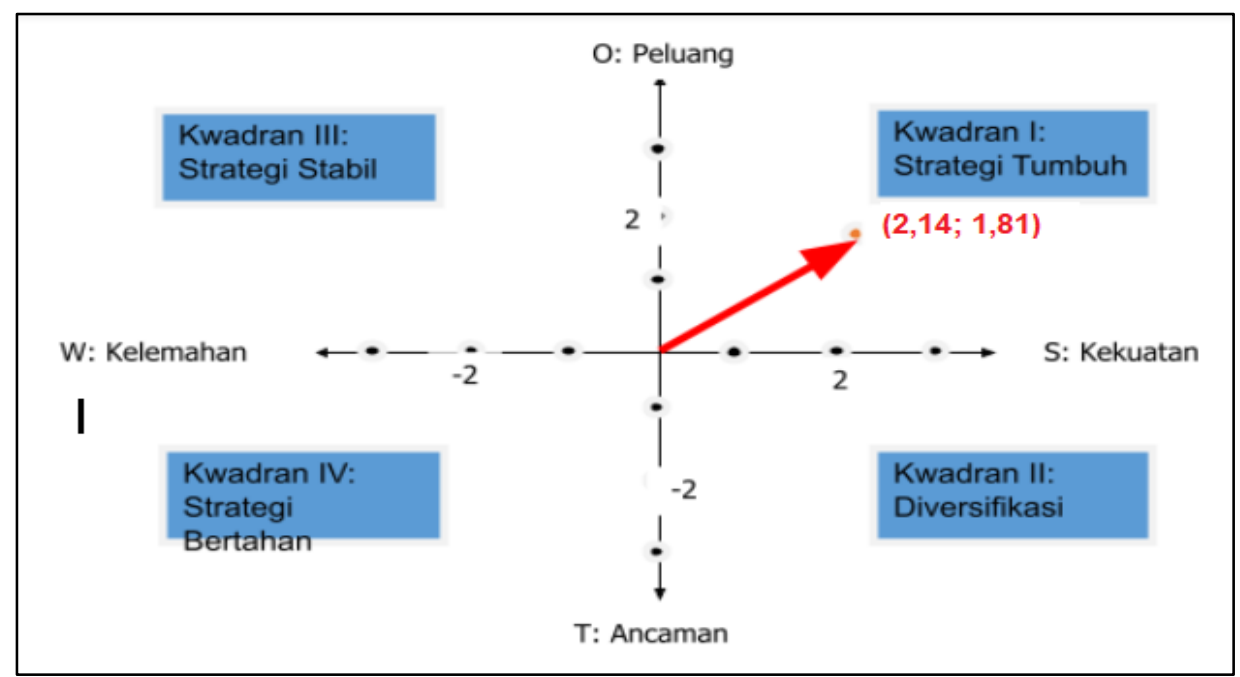

Gambar 2

Hasil Analisa Kuadran 
Selanjutnya akan dibuat matriks SWOT untuk penyelenggaran pelaksanaan industri hijau guna menghasikan alternatif strategi yang layak, seperti pada tabel matrik berikut.

Tabel 4

\section{Matrik SWOT}

\begin{tabular}{|c|c|c|}
\hline Faktor Eksternal & $\begin{array}{l}\text { KEKUATAN (S) } \\
\text { - Ada kebijakan dan regulasi } \\
\text { Pemda (Peraturan Daerah } \\
\text { terkait RPIP) dan Pemkab } \\
\text { (Perda RPIK) } \\
\text { - Ada program dan kegiatan } \\
\text { OPD lintas sektoral terkait } \\
\text { industri hijau, } \\
\text { - Ada laporan kegiatan } \\
\text { industri hijau } \\
\text { - Ada lembaga sertifikasi } \\
\text { industri hijau } \\
\text { Ada program penilaian } \\
\text { kinerja industri hijau }\end{array}$ & 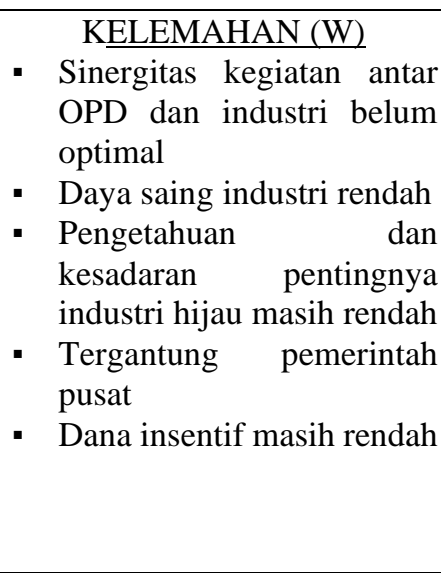 \\
\hline PELUANG $(\mathrm{O})$ & STRATEGI SO & STRATEGI WO \\
\hline $\begin{array}{l}\text { - Komitmen Kepala Daerah } \\
\text { besar terkait industri hijau } \\
\text { - Ada regulasi industri hijau } \\
\text { - Ada alokasi anggaran } \\
\text { program industri hijau } \\
\text { - Ada dukungan forum CSR } \\
\text { - Ada juknis industri hijau bagi } \\
\text { daerah }\end{array}$ & $\begin{array}{l}\text { - Peningkatan komitmen dan } \\
\text { koordinasi lintas sektoral } \\
(\mathrm{O} 1, \mathrm{O} 2, \mathrm{O} 4, \mathrm{~S} 1, \mathrm{~S} 2, \mathrm{~S} 3) \\
\text { - Peningkatan tata kelola } \\
\text { program industri hijau (O3, } \\
\mathrm{O} 5, \mathrm{~S} 4)\end{array}$ & $\begin{array}{ll}\text { - } & \text { Peningkatan } \\
& (\mathrm{W} 2, \mathrm{~W} 3, \mathrm{O} \text { ) } \\
\text { - } & \text { Kolaborasi } \\
& (\mathrm{W} 1, \mathrm{~W} 4, \mathrm{~W} 5, \mathrm{O} 1, \mathrm{O} 2, \mathrm{O} 3 \\
& \text {,O4) } \\
\text { - } & \begin{array}{l}\text { Peningkatan } \\
\text { industri (W2, W4) }\end{array}\end{array}$ \\
\hline TANTANGAN (T) & STRATEGI ST & STRATEGI WT \\
\hline 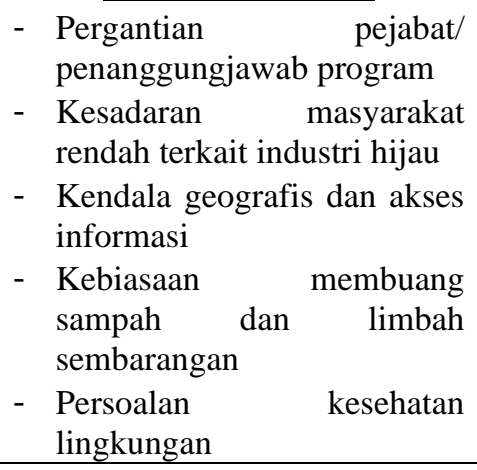 & $\begin{array}{l}\text { - Kampanye dan Sosialisasi } \\
\text { terkait Industri hijau (S1, } \\
\text { S2, S3, S4, T2, T4, T5) } \\
\text { - Komunikasi aktif (T1, T2, } \\
\text { T3, T4, T5, S1, S2, S4) }\end{array}$ & $\begin{array}{l}\text { - Peningkatan peran lintas } \\
\text { sektoral (W1, W2, W4, T1, } \\
\text { T3, T4, T5) } \\
\text { - Membangun mindset yang } \\
\text { baik di masyarakat } \\
\text { (T2,T3,T4,T5,WI,W2,W3, } \\
\text { W4) }\end{array}$ \\
\hline
\end{tabular}

Matrik IFE dan EFE menunjukkan total Skor Faktor Strategis Internal yaitu 3,38 dan total skor Faktor Strategis Eksternal yaitu 3,17. Selanjutnya hasil skor akan dipetakan ke dalam Tabel Matrik Internal Eksternal. Pada sumbu x dari matriks faktor strategis internal, total skor faktor strategis internal dari 1 hingga 1,99 dianggap rendah/lemah, nilai dari 2 hingga 2,99 adalah menengah, dan nilai dari 3,0 hingga 4,0 adalah tinggi, dan begitu pula dengan sumbu y dari matriks faktor strategis eksternal.

Skor hasil IFE sebesar 3,38 mengindikasikan bahwa faktor internal direspon tinggi. Skor hasil perhitungan EFE sebesar 3,17 mengindikasikan bahwa faktor eksternal direspon tinggi. Dari kondisi ini dapat diartikan bahwa faktor internal dan eksternal berpengaruh tinggi dalam penentuan langkah strategik pengembangan industri hijau di Jawa Timur. Pemetaan dari total skor yang diperoleh sebelumnya untuk internal dan eksternal, diindikasikan pada titik dalam sel I, seperti pada matriks berikut : 


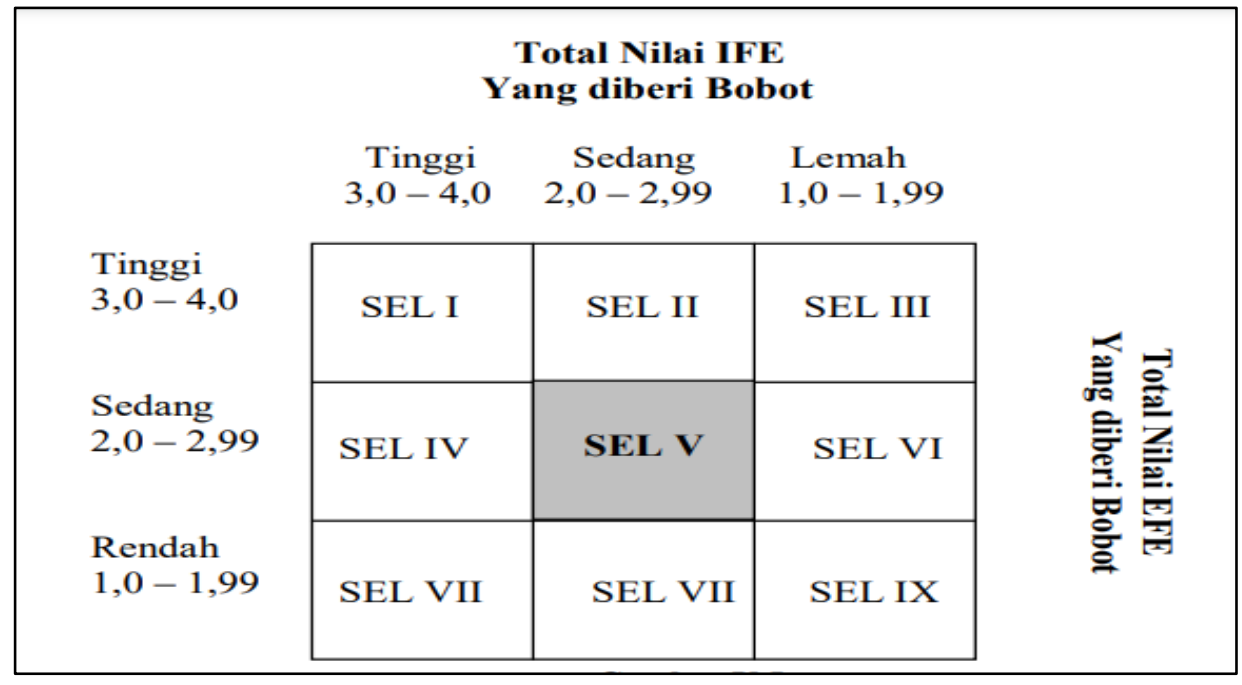

Gambar 3

Matrik Internal-Eksternal

Matriks IE dibagi menjadi 3 daerah utama yang memiliki implikasi strategi berbeda. Untuk kondisi pengembangan industri hijau di Jawa Timur maka menempati sel yang dapat digambarkan sebagai tumbuh dan kembangkan. Strategi yang paling sesuai adalah strategi intensif, berupa :

1. Meningkatkan akuntabilitas kinerja OPD lintas sektoral dalam pelaksanaan program industri hijau

2. Mendorong komitmen Pemerintah Kabupaten/Kota untuk menjadikan industri hijau sebagai prioritas pembangunan industri

3. Mendorong kesadaran, literasi dan perilaku multipihak untuk menerapkan industri hijau

4. Meningkatkan kerjasama lintas sektor OPD dan industri dalam menerapkan industri hijau.

Setelah dipetakan pada matrik diatas, terlihat bahwa total skor untuk faktor strategi internal berada di posisi kuat, sedangkan untuk faktor strategi eksternal berada di posisi tinggi, sehingga berada di sel I, yaitu pada kondisi tumbuh dan kembangkan. Hal ini mengindikasikan bahwa kondisi internal dan eksternal pada pengembangan industri hijau di Jawa Timur memiliki posisi pengaruh yang kuat dan berdaya tarik tinggi, sehingga harus terus ditumbuhkan dan dikembangkan. Strategi yang sesuai untuk digunakan berupa 4 strategi intensif.

Dari hasil analisis dengan pendekatan SWOT diatas, dihasilkan bahwa posisi penerapan industri hijau di Jawa Timur berada di kuadran I, yaitu menggunakan strategi growth (bertumbuh). Dari beberapa jenis strategi growth, untuk mendapatkan strategi yang cocok, maka dianalisis lebih lanjut dengan menggunakan Internal-Eksternal Matriks, dan hasilnya posisi penerapan industri hijau berada di daerah sel I, yaitu dengan 4 strategi intensif. Beberapa strategi diprioritaskan untuk dilaksanakan dalam penanganan stunting berdasarkan pendekatan SWOT maupun analisis Internal-Eksternal Matriks. Selanjutnya akan dianalisis dengan Matrik QSPM (Quantitative Strategic Planning Matrix) sebagai berikut:

Tabel 5

QSPM

\begin{tabular}{|c|c|c|c|c|c|c|c|c|c|c|}
\hline \multirow[t]{2}{*}{ No } & \multirow[t]{2}{*}{ Faktor Internal dan Ekternal } & \multirow[t]{2}{*}{ Bobot } & \multicolumn{2}{|c|}{ Strategi 1} & \multicolumn{2}{|c|}{ Strategi 2} & \multicolumn{2}{|c|}{ Strategi 3} & \multicolumn{2}{|c|}{ Strategi 4} \\
\hline & & & AS & TS & AS & TS & AS & TS & AS & TS \\
\hline & Kekuatan (Strength) & & & & & & & & & \\
\hline 1 & $\begin{array}{l}\text { Ada kebijakan dan regulasi } \\
\text { Pemda (Peraturan Daerah terkait } \\
\text { RPIP) dan Pemkab (Perda RPIK) }\end{array}$ & 0.14 & 4 & 0.56 & 4 & 0.56 & 3 & 0.42 & 4 & 0.56 \\
\hline 2 & $\begin{array}{l}\text { Ada program dan kegiatan OPD } \\
\text { lintas sektoral terkait industri } \\
\text { hijau, }\end{array}$ & 0.14 & 4 & 0.56 & 4 & 0.56 & 2 & 0.28 & 4 & 0.56 \\
\hline 3 & $\begin{array}{l}\text { Ada laporan kegiatan industri } \\
\text { hijau }\end{array}$ & 0.13 & 4 & 0.52 & 3 & 0.39 & 1 & 0.13 & 3 & 0.39 \\
\hline 4 & $\begin{array}{l}\text { Ada lembaga sertifikasi industri } \\
\text { hijau }\end{array}$ & 0.14 & 4 & 0.56 & 3 & 0.42 & 4 & 0.56 & 4 & 0.56 \\
\hline
\end{tabular}


$\begin{array}{lllllllllll}5 & \text { Ada program penilaian kinerja } & 0.14 & 4 & 0.56 & 4 & 0.56 & 1 & 0.14 & 4 & 0.56\end{array}$ industri hijau (proper)

Kelemahan (Weakness)

1 Sinergitas kegiatan antar OPD dan industri belum optimal

2 Daya saing industri rendah

3 Pengetahuan dan kesadaran pentingnya industri hijau masih rendah

4 Tergantung pemerintah pusat

5 Dana insentif masih rendah

$\begin{array}{lllllllll}0.08 & 4 & 0.32 & 4 & 0.32 & 3 & 0.24 & 4 & 0.32 \\ 0.07 & 4 & 0.28 & 3 & 0.21 & 2 & 0.14 & 2 & 0.14 \\ 0.08 & 3 & 0.24 & 2 & 0.16 & 4 & 0.32 & 3 & 0.24 \\ 0.08 & 3 & 0.24 & 3 & 0.24 & 3 & 0.24 & 2 & 0.16 \\ 0.08 & 3 & 0.24 & 2 & 0.16 & 4 & 0.32 & 3 & 0.24\end{array}$

Peluang (Opportunities)

1 Komitmen Kepala Daerah besar terkait industri hijau

$\begin{array}{lllllllll}0.14 & 3 & 0.42 & 4 & 0.56 & 2 & 0.28 & 3 & 0.42\end{array}$

2 Ada regulasi industri hijau

3 Ada alokasi anggaran program industri hijau

$\begin{array}{lllllllll}0.14 & 3 & 0.42 & 4 & 0.56 & 2 & 0.28 & 3 & 0.42\end{array}$

$\begin{array}{lllllllll}0.11 & 2 & 0.22 & 4 & 0.44 & 4 & 0.44 & 4 & 0.44\end{array}$

4 Ada dukungan forum CSR

$\begin{array}{lllllllll}0.12 & 2 & 0.24 & 3 & 0.36 & 4 & 0.48 & 4 & 0.48\end{array}$

5 Ada juknis industri hijau bagi daerah Tantangan (Threaths)

1 Pergantian pejabat/ penanggungjawab program

2 Kesadaran masyarakat rendah terkait industri hijau

3 Kendala geografis dan akses informasi

$\begin{array}{lllllllll}0.14 & 4 & 0.56 & 2 & 0.28 & 2 & 0.28 & 2 & 0.28\end{array}$

4 Kebiasaan membuang sampah dan limbah sembarangan 0.07

5 Persoalan kesehatan lingkungan TOTAL

\begin{tabular}{lllllllll}
0.07 & 4 & 0.28 & 2 & 0.14 & 2 & 0.14 & 2 & 0.14 \\
0.08 & 2 & 0.16 & 2 & 0.16 & 4 & 0.32 & 2 & 0.16 \\
0.07 & 2 & 0.14 & 3 & 0.21 & 3 & 0.21 & 4 & 0.28 \\
0.07 & 2 & 0.14 & 4 & 0.28 & 4 & 0.28 & 4 & 0.28 \\
0.06 & 2 & 0.12 & 4 & 0.24 & 4 & 0.24 & 4 & 0.24 \\
\hline
\end{tabular}

AS1: tidak ada keterkaitan; AS2: Ada keterkaitan; AS3: dapat terkait; AS4: sangat terkait

Berdasarkan hasil analisis QSPM (lihat Tabel 5) dapat dilihat strategi terbaik yang dapat dilakukan saat ini adalah mendorong komitmen Pemerintah Kabupaten/Kota untuk menjadikan industri hijau sebagai prioritas pembangunan industri di daerah. Strategi ini dilakukan sebagai upaya untuk memastikan pengembangan industri hijau sebagai arus utama dalam arah kebijakannya dengan nilai Total Attractiveness Score (TAS) tertinggi, yaitu sebesar 6,63.

Berikut adalah urutan Strategi Prioritas berdasarkan skoring QSPM, yakni:

1. Mendorong komitmen Pemerintah Kabupaten/Kota untuk menjadikan industri hijau sebagai prioritas dalam pembangunan industri

2. Meningkatkan Kerjasama lintas sektor dalam penerapan industri hijau

3. Meningkatkan akuntabilitas kinerja/tata kelola OPD dalam pelaksanaan program industri hijau

1. Mendorong Kesadaran, Literasi dan Perilaku multipihak terkait pentingnya penerapan industri hijau.

Selanjutnya, multi aktor/multi pihak perlu terus melakukan kolaborasi dalam rangka penerapan industri hijau sesuai dengan tugas dan fungsinya. Berikut skema strategi pengembangan industri hijau yang bisa diterapkan dalam lingkup daerah, baik provinsi maupun kabupaten/kota. Strategi pengembangan industri hijau yang bisa dilakukan oleh Pemerintah Daerah dan multipihak lainnnya adalah sebagai berikut:

1. Mengembangkan industri yang sudah ada menuju industri hijau.

2. Membangun industri baru dengan prinsip industri hijau

3. Pemenuhan terhadap standar industri hijau sebagai wujud penerapan industri hijau. 
Hal ini relevan dengan pernyataan Menteri Perindustrian Saleh Husin bahwa ada 2 strategi dalam mewujudkan industri hijau, Pertama, Mengembangkan industri yang sudah ada menuju industri hijau (greening of existing industries). Kedua, Membangun industri baru dengan suatu penerapan prinsip-prinsip industri hijau(creation of new green industries).

Pengembangan industri yang sudah ada menuju industri hijau dapat dilakukan melalui berbagai upaya antara lain: (1) Rencana penerapan 5 standar industri hijau, yaitu: industri tekstil, ubin keramik, semen, baja, serta pulp dan kertas; (2) Penerbitan Katalog bahan baku ramah lingkungan untuk industri tekstil, ubin keramik, dan makanan; (3) Pedoman umum dan teknis konservasi energi dan pengurangan emisi gas CO2; (4) Panduan teknis untuk studi kelayakan untuk implementasi Konservasi Energi dan Pengurangan Emisi CO2; (5) Panduan pengolahan limbah cair, bahan berbahaya dan beracun (B3); (6) Panduan produksi bersih; (7) Program restukturasi mesin untuk industri gula, industri tekstil dan produk tekstil serta industri kulit dan alas kaki yang telah dilakukan sejak tahun 2007; serta (8) Pemberian penghargaan Industri Hijau. Sedangkan, untuk pembangunan industri baru akan diterapkan prinsip-prinsip Industri Hijau dalam proses produksinya seperti penggunaan bahan baku, energi, dan air yang efisien. Insentif yang bisa diberikan untuk industri yang telah menerapkan industri hijau berupa peningkatan kapasitas sumber daya manusia (SDM) perusahaan industri, dukungan promosi, serta penyediaan tenaga ahli audit energi, air dan bahan baku.

Lebih lanjut mengenai konsep industri hijau, yang mengutamakan efisiensi dalam proses produksi dengan karakteristik sebagai berikut: penggunaan material, energi, dan air dengan intensitas yang rendah; penggunaan energi alternatif; melakukan minimisasi limbah dan pemenuhan baku mutu lingkungan; menggunakan teknologi rendah karbon dan SDM yang kompeten.

Menurut data dari Dinas Lingkungan Hidup (DLH) Provinsi Jawa Timur, penilaian DLH Jawa Timur terhadap pengelolaan industri cukup bagus. Penilaian itu berdasar penanganan limbah oleh perusahaan yang berlangsung selama 2020. Dari 195 perusahaan yang dinilai di Jawa Timur, tidak ada satu pun yang masuk kategori hitam. Menurut Plt Kepala Dinas Lingkungan Hidup Jawa Timur Sunarto mengungkapkan, ada lima kategori pada penilaian tersebut. Yakni emas, hijau, biru, merah, dan hitam. Kategori tersebut berdasar urutan pencapaian penilaian. Hitam merupakan kategori yang patut dihindari. Sebab, kategori tersebut membuktikan pengelolaan lingkungan hidup bagi industri belum maksimal. Sementara itu, terdapat 4 perusahaan di Jawa Timur yang meraih predikat emas. Selain itu, sebanyak 10 perusahaan masuk kategori hijau, untuk biru 171 perusahaan, dan merah 10 perusahaan. Jadi, tidak ada yang masuk predikat hitam. Perusahaan yang diaudit berlokasi di sepanjang daerah aliran Sungai Brantas. Daerah dengan jumlah perusahaan paling banyak adalah Surabaya. Daerah berikutnya adalah Sidoarjo 30 perusahaan, Gresik 23 perusahaan, dan Mojokerto 12 perusahaan.

DLH Provinsi Jawa Timur selalu mengimbau perusahaan untuk taat dalam menjalankan program pengelolaan lingkungan. Program itu berlangsung sejalan dengan kegiatan usahanya. Kinerjanya setiap tahun akan diaudit oleh Kementerian Lingkungan Hidup dan Kehutanan. dua program yang menjadi prioritas di tahun ini. Yakni sistem informasi pengelolaan sampah dan layanan silabi. Sistem informasi pengelolaan sampah bisa diakses melalui website atau apilkasi. Program tersebut menguatkan data tentang sampah di 38 kabupaten dan kota.

Pencapaian kinerja perusahaan di Jawa Timur dalam mengelola lingkungan cukup baik. Hal ini berkat kerja sama antara perusahaan dan pemerintah. Selain itu, tingkat partisipasi pelaku usaha industri di Jawa Timur yang cukup tinggi. Dengan penerapan industri hijau melalui penggunaan teknologi rendah karbon, tentunya akan memberikan dampak penghematan energi, air dan bahan baku. Selain itu juga akan meningkatkan produktivitas dan menghasilkan limbah yang lebih sedikit.

\section{KESIMPULAN DAN SARAN}

Hasil estimasi menggunakan DEA menunjukkan bahwa masih banyak industri yang belum efisien dalam proses produksi. Hal ini dapat ditunjukkan dengan nilai DEA masih belum 1. Selanjutnya, analisa implementasi green industry pada sampel industri di Jawa Timur, yaitu:

1. Multipihak/Multi aktor cukup berperan dalam penerapan industri hijau

2. Analisa Internal, terdiri atas kekuatan utama yang dimiliki Provinsi Jawa Timur adalah: ada kebijakan dan regulasi Pemerintah daerah (Peraturan Daerah terkait Rencana Pembangunan Industri Propinsi-RPIP) dan Pemerintah kabupaten (Peraturan Daerah tentang Rencana Pembangunan Industri Kabupaten-RPIK), ada program dan kegiatan dari organisasi perangkat daerah OPD lintas sektoral terkait industri hijau, dan ada lembaga sertifikasi industri hijau. Sedangkan, kelemahan yang 
dimiliki adalah: Sinergitas kegiatan antar OPD dan industri belum optimal, daya saing industri rendah, pengetahuan dan kesadaran pentingnya industri hijau masih rendah, tergantung pemerintah pusat, dan dana insentif masih rendah

3. Analisa Ekternal, terdiri atas: Peluang yang dimiliki Provinsi Jawa Timur adalah: komitmen Kepala Daerah besar terkait industri hijau, ada regulasi industri hijau, ada alokasi anggaran program industri hijau, ada dukungan forum corporat social responsible-CSR, ada juknis industri hijau bagi daerah. Sedangkan, tantangan yang ada adalah: pergantian pejabat / penanggungjawab program, kesadaran masyarakat rendah terkait industri hijau, kendala geografis dan akses informasi, kebiasaan membuang sampah dan limbah sembarangan, persoalan kesehatan lingkungan.

Rekomendasi Kebijakan:

1. Orientasi green Industry harus menjadi mindset industri

2. Tanggung jawab perusahaan dalam hal CSR dan EPR harus ditunaikan

3. Membentuk Roadmap Percepatan Green Industry

\section{DAFTAR PUSTAKA}

Anom Prianto, Elva Fairuz Anbia, Grace Margaretha Retno Wulan, \& Nelson Panggabean. (2021). Tinjauan Penerapan Ekonomi Hijau Dalam Pariwisata Di Provinsi Bali Review of the Application of Green Economy in Tourism in Bali Province. Jurnal Indonesia Sosial Teknologi, 2(1), 16-22. https://doi.org/10.36418/jist.v2i1.74

Assidikiyah, N., Marseto, M., \& Sishadiyati, S. (2021). Analisis Potensi Pertumbuhan Ekonomi Provinsi Jawa Timur (sebelum Dan Saat Terjadi Pandemi Covid-19). Jambura Economic Education Journal, 3(2), 102-115. https://doi.org/10.37479/jeej.v3i2.11017

Astutiningsih, S. E., \& Sari, C. M. (2017). Pemberdayaan Kelompok Agroindustri Dalam Upaya Mempercepat Pertumbuhan Ekonomi Jawa Timur. Jurnal Ilmu Ekonomi Terapan, 2(1), 1-20. https://doi.org/10.20473/jiet.v2i1.5500

Chrismastianto, I. A. W. (2017). Analisis Swot Implementasi Teknologi Finansial Terhadap Kualitas Layanan Perbankan Di Indonesia. Jurnal Ekonomi dan Bisnis, 20(1), 133-144.

Firdaus, M. faza, \& Hosen, M. N. (2014). Efisiensi Bank Umum Syariah Menggunakan Pendekatan Two-Stage Data Envelopment Analysis. Buletin Ekonomi Moneter dan Perbankan, 16(2), 167 188. https://doi.org/10.21098/bemp.v16i2.31

Noor, S. (2014). Penerapan Analisis Swot Dalam Menentukan Strategi Pemasaran Daihatsu Luxio Di Malang. Jurnal INTEKNA, 14(2), 19-34.

Prianto, A., \& Sulhan, M. (2020). Evaluasi Kebijakan Pembangunan Industri Dijawa Timur Yang Berwawasan Sumber Daya Manusia Dalam Sustainability Development. Publisia: Jurnal Ilmu Administrasi Publik, 5(1), 61-68. https://doi.org/10.26905/pjiap.v5i1.3647

Putri, S. F. (2020). Hubungan Pembangunan Ekonomi Terhadap Kualitas Lingkungan Hidup Di Provinsi Jawa Timur. JURNAL DINAMIKA EKONOMI PEMBANGUNAN, 2(2), 58. https://doi.org/10.14710/jdep.2.2.58-70

Setyaningsih, E. D. (2018). Analisis SWOT Implementasi Financial Technology Syariah Pada Pt Telkom Indonesia. Syi ar Iqtishadi : Journal of Islamic Economics, Finance and Banking, 2(2), 73-91. https://doi.org/10.35448/jiec.v2i2.4386

Sjafii, A. (2009). Pengaruh Investasi Fisik Dan Investasi Pembangunan Manusia Terhadap Pertumbuhan Ekonomi Jawa Timur 1990-2004. Journal of Indonesian Applied Economics, 3(1), 59-76. https://doi.org/10.21776/ub.jiae.2009.003.01.3

Sutawijaya, A., \& Lestari, E. P. (2009). Efisiensi Teknik Perbankan Indonesia Pascakrisis Ekonomi: Sebuah Studi Empiris Penerapan Model Dea. Jurnal Ekonomi Pembangunan: Kajian Masalah Ekonomi dan Pembangunan, 10(1). https://doi.org/10.23917/jep.v10i1.808

Sutikno, B., Pudyaningsih, A. R., \& Hastari, S. (2021). Pengaruh Potensi Ekonomi Terhadap Pembangunan Ekonomi Hijau Melalui Kearifan Lokal Dan Peran Koperasi Susu Di Kabupaten Pasuruan. 6(1).

Tuffahati, H., Mardian, S., \& Suprapto, E. (2019). Pengukuran Efisiensi Asuransi Syariah Dengan Data Envelopment Analysis (DEA). Jurnal Akuntansi dan Keuangan Islam, 4(1), 1-23. https://doi.org/10.35836/jakis.v4i1.27 